УДК 58.032:588.762.2

\title{
Посухостійкість представників роду Cotinus Mill. в умовах Правобережного Лісостепу України
}

\author{
Валентина М. Оксантюк ${ }^{1}$, Лариса А. Колдар ${ }^{1}$ \\ ${ }^{1}$ Національний дендрологічний парк «Софіївка» НАН України, м. Умань, Черкаської обл., Україна, \\ e-mail: valynchuk1@rambler.ru \\ ORCID ID0000-0001-5590-0629 \\ e-mail: koldar55@ukr.net \\ ORCID ID0000-0002-6756-4172
}

\section{Реферат.}

Mema. Дослідити фактичну та потенџійну посухостійкість у представників роду Cotinus Mill. в умовах Правобережного Лісостепу України. Матеріали і методи. Об’єктами дослідження були: С. coggygria, C. obovatus, C. coggygria 'Purpurea' та C. coggygria 'Royal Purple'. Дослідження проводили впродовж вегетаџійного сезону

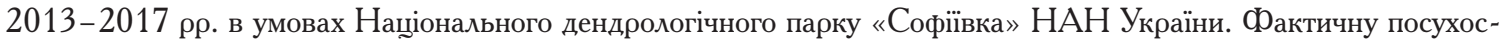
тійкість досліджували використовуючи візуальний метод С. С. Пятниџького (1961). Потенџійну посухостійкість визначали лабораторним методом, запропонований М. Д. Кушніренко (1975), масу листків визначали за допомогою терезів ВЛКТ-500-М з точністю до 0,001 г. Дослідження проводили у ранішні години літніх місяџів у II-III декаді кожного місяџя. Відбирали по 25 листків з різних сторін крони, пакували у пакети та швидко переносили до лабораторії. Визначали такі параметри: вміст загальної води в листках, дефіџит води в листках, тургоровідновлюючу та водоутримувальну здатності. Результати. Дослідження показали, шо вміст загальної води упродовж вегетаџійного періоду є відносно стабільним, і її вміст до кінџя літніх місяџів складає від 60,22 до 68,74\%. Зниження кількості загальної води, в кінџі серпня, в листках Cotinus можна пояснити початком некротичних проџесів. Залежно від варіювання метеорологічних даних, в періоди дослідження, ми спостерігали різниџю у показниках водного дефіџиту рослин представників роду Cotinus. 3 підвишенням температури, зменшенням відносної вологості повітря та кількості опадів, водний дефіџит рослин роду Cotinus різко зростав. Повне відновлення тургору листків спостерігали після втрати 15,0\% води. При втраті більше 15,0\% води спостерігали незворотні пошкодження листкових пластинок. Найбільш стійкими до зневоднення виявилися листки C. coggygria. Після насичення водою листків $C$. coggygria, які втратили 35,0\% води, відновлено тургору 75,4\% площі листків, тоді як у C. obovatus џей показник становив 63,2\%. Водоутримуюча здатність представників роду Cotinus показала, шо листки всіх досліджуваних рослин досягали 35 -відсоткового рівня втрати води впродовж 20-24 годин. При џьому найшвидше випаровували воду листки C. obovatus, які втратили 35,0\% води за 20 годин, повільніше C. coggygria 32,1\%, C. coggygria 'Royal Purple' - 25,8\%, C. coggygria 'Purpurea' - 26,0\% відповідно. Висновки. Встановлено, џо в умовах Наџіонального дендрологічного парку «Софіївка» НАН України досліджувані рослини роду Cotinus характеризуються високою фактичною посухостійкістю. Вміст загальної води упродовж вегетаџійного періоду є відносно стабільним, і їі вміст до кінџя літніх місяџів складав від 60,22 до 68,74\%. У листках представників роду Сotinus виявлено низький дефіџит в період посухи та високу стійкість до зневоднення, џо є ознаками посухостійкості рослин. Аналіз отриманих даних результатів досліджень дає можливість стверджувати, шо рослини представників роду Cotinus $€$ посухостійкими, а відповідно придатними для широкого використання в зеленому будівниџтві.

Ключові слова: Cotinus Mill., вміст загальної води, дефіџит води, тургоровідновлююча і водоутримувальна здатність. 


\title{
Drought Tolerance of the Cotinus Mill. Genus Representatives in Conditions of the Right Bank Forest-Steppe of Ukraine
}

\author{
Valentina M. Oksantiuk ${ }^{1}$, Larysa A. Koldar ${ }^{1}$ \\ ${ }^{1}$ National Dendrology Park «Sofiyivka» of the National Academy of Sciences of Ukraine, Uman, Cherkasy region, Ukraine, \\ e-mail: valynchuk1@rambler.ru \\ ORCID ID0000-0001-5590-0629 \\ e-mail: koldar55@ukr.net \\ ORCID ID0000-0002-6756-4172
}

\begin{abstract}
.
Aims. To investigate the actual and potential drought tolerance of the Cotinus Mill genus representatives in conditions of the Right Bank Forest-Steppe of Ukraine. Materials and methods. The objects of the study were the following: C. coggygria, C. obovatus, C. coggygria 'Purpurea' and C. coggygria 'Royal Purple'. The research was conducted during the growing season of 2013-2017 in conditions of the National Dendrology Park «Sofiyivka» of the National Academy of Sciences of Ukraine. Actual drought tolerance was investigated using the visual method of S.S. Pyatnytsky (1961). Potential drought tolerance was determined by the laboratory method proposed by M. D. Kushnirenko (1975). The mass of leaves was determined by using the weights of VLKT 500-M with an accuracy of $0,001 \mathrm{~g}$. The research was conducted in the early hours of the summer months of 2013-2017 in the $2^{\text {nd }}$ and $3^{\text {rd }}$ decade of each month. We picked up 25 leaves from different sides of the crown, packed them and quickly transferred to the laboratory. The following parameters were determined: the total water content in the leaves, the lack of water in the leaves, the turgor rejuvenating and water retention capacity. Results. The studies have shown that the total water content during the growing season is relatively stable, and its content is from 60,22 to $68,74 \%$ by the end of the growing season. Reducing the amount of total water at the end of August in the Cotinus leaves can be explained by the beginning of necrotic processes. Depending on the variation of meteorological data during the study period, we observed a difference in the water deficit of plants of the Cotinus genus representatives. The water shortage of the Cotinus genus plants increases sharply together with rising temperatures, decreasing the relative air humidity and precipitation amount. The complete turgor leaves recovering had been followed after losing $15,0 \%$ of water. In case of loss of more than $15,0 \%$ of water, the irreversible damage to the leaf blades was observed. The leaves of $C$. coggygria were the most resistant to dehydration. After saturated with water, the leaves of $C$. coggygria, which had lost $35,0 \%$ of water, restored the turgor to $75,4 \%$ of the leaf area, whereas in the C. obovatus this figure was $63,2 \%$. The water-repellent ability of the Cotinus genus representatives has shown that the leaves of all studied plants reached 35-percent level of water loss in 20-24 hours. At the same time, the C. obovatus leaves evaporated water the fastest. They lost 35,0\% of water in 20 hours, C. coggygria lost 32,1\%, C. coggygria 'Royal Purple' lost 25,8\%, and C. coggygria 'Purpurea' lost 26,0\% respectively. Conclusions. It has been stated that in conditions of the National Dendrology Park «Sofiyivka» of the National Academy of Sciences of Ukraine, the plants of Cotinus genus are characterized by high actual drought tolerance. Laboratory studies have shown that the total water content during the growing season is relatively stable, and its content is from 60,22 to $68,74 \%$ by the end of the summer months. In the leaves of the Cotinus genus representatives, a low deficit is seen in the period of drought tolerance and high resistance to dehydration, which is evidence of drought-tolerance of plants. The analysis of the data obtained from the research results suggests that the representatives of the Cotinus genus are drought tolerant and suitable for wide use in green building.
\end{abstract}

Key words: Cotinus Mill., total water content, water deficit, turgor recovery and water retention capacity.

Вступ/Introduction. Одним з основних показників стійкості рослин є посухостійкість, яку розглядають як здатність витримувати більш або менш тривалі посухи без значних незворотних порушень життєвих функџій (Klymenko, 1999). Від забезпеченості рослин водою залежить не лише ріст і продуктивність рослин, але і їх зимостійкість, довговічність, що важливо при підборі порід для вирошування в різних умовах зволоження (Kushnirenko, 1975).

Посухостійкість, џе властивість, пов'язана зі здатністю рослини витримувати перегрів і зневоднення. Посухостійкими рослинами вважають ті, які здатні в проџесі онтогенезу пристосовуватись до дії посухи і здійснювати в џих умовах ріст, розвиток і відновлення завдяки наявності в них властивостей, 
які виникли в проџесі філогенезу під впливом умов існування і природного добору. Можливості рослин подолати значний водний стрес тим більші, чим вища ix здатність уникати висихання і чим більше може зневоднюватись протоплазма клітин без згубних наслідків (Genkel' \& Oknina, 1954; Kushnirenko et al. 1975; Kushnirenko, 1975; Kushnirenko, 1962; Lishchuk, 1980).

Посухостійкість деревних рослин залежить від багатьох факторів, у тому числі від тих, шо затримують зневоднення (площа і структура листків, осмотичний тиск), і тих, шо сприяють рослинам виживати за умов зневоднення (розмір та форма клітин, властивості протоплазми). Деякі деревні рослини, добре витримуючи посуху, не мають вираженої фізіологічної здатності витримувати зневоднення клітин. Џе такі рослини, у яких добре розвинена коренева система, або вони здатні в період посухи дуже зменшувати листкову поверхню, а отже і витрати на транспіраџію. До таких рослин належать представники роду Cotinus Mill. родини Anacardiaceae Lindley. До роду Cotinus Mill. належать два види C. coggygria Scop. та C. obovatus Raf. і їхні декоративні форми, сорти та гібриди (Oksantiuk, 2018).

Малопоширеним в Україні є інтродукований вид - C. obovatus. За життевою формою џе розлогі куші або дерева заввишки 10-12 м з еліптичними листками 6-12 см завдовжки. Природні ареали
C. obovatus займають територію північного та південного сходу Америки: штати Техас, Оклахома, Miссурі, Арканзас, Алабама, Теннессі.

Природні ареали С. coggygria розташовані в помірних районах Євразії, Середземномор’ї, Малій Азії, Китаї та Гімалаях. В Україні представники роду поширені в Лісостеповій і Степовій зонах, у передгір'ях Криму вздовж Чорноморського узбережжя.

Мета - дослідити фактичну та потенџійну посухостійкість у представників роду Cotinus Mill. в умовах Правобережного Лісостепу України.

Матеріали і методи/Materials and methodology.

Об'єктами дослідження були: С. coggygria, C. obovatus, C. coggygria 'Purpurea' та C. coggygria 'Royal Purple'. Дослідження проводили впродовж вегетаџійного сезону 2013-2017 рр. в умовах Наџіонального дендрологічного парку «Софіївка» НАН України. Незважаючи на те, що в зоні Правобережного $\mathrm{\lambda i}_{\text {- }}$ состепу України посуха не є лімітуючим чинником, який впливає на розвиток більшості деревних рослин, і територія НДП «Софіївка» НАН України розташована в межах помірно-континентального клімату із середньою багаторічною температурою $+7,4{ }^{\circ} \mathrm{C}$, за даними Уманської гідрометеостанџї, в окремі роки тут було зафіксовано періоди посухи (дефіџит вологи), особливо влітку 2017 року (табл. 1).

Таблиџя 1. Середньомісячні та середні багаторічні метеорологічні показники за травень-серпень місяџі 2013-2017 років в умовах НДП «Софіївка» НАН України (за даними метеостануії в м. Умань)

Table 1. Average monthly and average perennial climatic indicators for May-August of the month of 2013-2017 in conditions of the NDP «Sofiyivka» of the National Academy of Sciences of Ukraine (according to the weather station in Uman)

\begin{tabular}{|c|c|c|c|}
\hline $\begin{array}{c}\text { Miсяџь } \\
\text { Month }\end{array}$ & $\begin{array}{c}\text { Середня температура, }{ }^{\circ} \mathrm{C} \\
\text { Average temperature, }{ }^{\circ} \mathrm{C}\end{array}$ & $\begin{array}{c}\text { Відносна вологість повітря, } \% \\
\text { Relative humidity, } \%\end{array}$ & $\begin{array}{c}\text { Опади, мм } \\
\text { Precipitation, } \mathrm{mm}\end{array}$ \\
\hline \multicolumn{5}{|c|}{2013} \\
\hline Травень/May & 18,4 & 67 & 70,9 \\
\hline Червень/ June & 20,5 & 72 & 77,8 \\
\hline Липень/ July & 20,0 & 71 & 23,2 \\
\hline Серпень/ August & 19,8 & 69 & 54,4 \\
\hline \multicolumn{5}{|c|}{2014} & 125,0 \\
\hline Травень/May & 16,1 & 73 & 73,0 \\
\hline Червень/June & 17,5 & 72 & 52,9 \\
\hline Липень/July & 21,5 & 70 & 15,9 \\
\hline Серпень/August & 20,8 & 65 & \\
\hline
\end{tabular}




\begin{tabular}{|c|c|c|c|}
\hline 1 & 2 & 3 & 4 \\
\hline \multicolumn{4}{|c|}{2015} \\
\hline Травень/Мау & 15,6 & 66 & 41,1 \\
\hline Червень/June & 19,3 & 64 & 113,0 \\
\hline Липень/July & 21,3 & 68 & 48,0 \\
\hline Серпень/August & 21,2 & 60 & 17,0 \\
\hline \multicolumn{4}{|c|}{2016} \\
\hline Травень/Мау & 14,7 & 73 & 117,0 \\
\hline Червень/June & 20,0 & 73 & 75,0 \\
\hline Липень/July & 21,6 & 67 & 16,0 \\
\hline Серпень/August & 20,6 & 68 & 27,0 \\
\hline \multicolumn{4}{|c|}{2017} \\
\hline Травень/Мау & 14,9 & 63 & 48,0 \\
\hline Червень/June & 20,0 & 64 & 40,0 \\
\hline Липень/July & 20,6 & 65 & 59,0 \\
\hline Серпень/August & 20,6 & 68 & 27,0 \\
\hline \multicolumn{4}{|c|}{ Середні багаторічні дані/ Average long-term data } \\
\hline Травень/Мау & 16,7 & 67 & 79,0 \\
\hline Червень/June & 19,1 & 69 & 87,3 \\
\hline Липень/July & 20,9 & 70 & 41,3 \\
\hline Серпень/August & 20,6 & 65 & 29,1 \\
\hline
\end{tabular}

Потенџійну посухостійкість визначали лабораторним методом, запропонований М. Д. Кушніренко (1975), масу листків визначали за допомогою терезів ВЛКТ-500-М з точністю до 0,001 г. Дослідження проводили у ранішні години літніх місяџів у II-III декаді кожного місяџя. Відбирали по 25 листків з різних сторін крони, пакували у пакети та швидко переносили до лабораторії (Kushnirenko et al. 1975). Визначали такі параметри: вміст загальної води в листках, дефіџит води в листках, тургоровідновлюючу та водоутримувальну здатності (втрата води від вихідної сирої маси) в проџесі в'янення через певний проміжок часу $(2,4,6,8,10,12,24$ год.). Під водоутримувальною здатністю приймається втрата води за певний проміжок часу (через кожні 2 год.), яка виражена у відсотках до початкового вмісту її у листках; загальна вода наводиться у відсотках від сирої маси; водний дефіџит - џе дефіџит води в листках, виражений у відсотках від його загального вмісту в стані повного насичення. Дослідження виконували у трикратній повторності. Листки для аналізу заготовляли вранџі (при повному тургорі) і негайно зважували. У проџесі в'янення листків проводили повторні зважування џогодини, аж до досягнення $35 \%$ втрати води у розрахунку на сиру речовину. Встановлювали граничну точку зневоднення, за якого листки зберігали спроможність до повного відновлення тургору, а також відсоток листків здатних відновлювати тургор після 35\% втрати води. Для оџінювання здатності відновлювати тургор, зневоднені листки розмішували між двома вологими листками фільтрувального паперу на 8-12 годин, після чого у неушкоджених листках відновлювався тургор. Повне відновлення тургору листкових пластинок фіксували, якшо після насичення зів'ялих листків водою, у них не було помітно ознак відмирання чи в' янення.

Результати та обговорення/Results and Discussion. Зважаючи на дані М. Д. Кушніренко та ін., якими з'ясовано, шо максимальна різниџя в посухостійкості між видами спостерігається в умовах з недостатньою вологістю (в серпні) і практично відсутня у травні, коли в грунті є достатня кількість вологи, яка утримується після танення снігу (Borzakivs'ka, 1965; Kratkij agroklim...1976; Kushnirenko et al. 1970). Тому, ми проаналізували середньомісячні та середні багаторічні метеодані фактичної 
кількості атмосферних опадів за травень-серпень місяџі 2013-2017 років (див. табл. 1).

Кількість опадів, упродовж різних років, є величиною несталою і шорічно змінюється Шодо відносної вологості повітря досліджуваного регіону, за середніми багаторічними спостереженнями даний показник є відносно стабільним і перебуває в межах 65-70\%. Хоча посушливі умови, які зазвичай не були характерними для Правобережного Лісостепу України, склалися влітку 2017 року. Найменшу кількість опадів зафіксовано у травні, червні та серпні - 48,0; 40,0 та 27,0 мм відповідно (див. табл. 1).

Отже, метеорологічні дані вказують на потенџійну можливість виникнення посушливих умов у 2017 роџі, а наявність ушкоджень листків у џей рік стала приводом для оџінки посухостійкості досліджуваних представників роду Cotinus. Варто вказати, шо в 2013-2016 роках у досліджуваних рослин ніяких ушкоджень внаслідок посухи не спостерігали, і за шкалою С. С. Пятниџького їх оџінено в 5 балів (табл. 2).

Таблиџя 2. Посухостійкість представників роду Cotinus (бали)

Table 2. Drought tolerance of the Cotinus genus representatives (points)

\begin{tabular}{|l|c|c|c|c|c|}
\hline \multirow{2}{*}{\multicolumn{1}{|c|}{ Таксон/Taxon }} & \multicolumn{5}{c|}{ Рік/Year } \\
\cline { 2 - 6 } & 2013 & 2014 & 2015 & 2016 & 2017 \\
\hline C. coggygria & 5 & 5 & 5 & 5 & 5 \\
\hline C. obovatus & 5 & 5 & 5 & 5 & 4 \\
\hline C. coggygria 'Purpurea' & 5 & 5 & 5 & 5 & 4 \\
\hline C. coggygria 'Royal Purple' & 5 & 5 & 5 & 5 & 4 \\
\hline
\end{tabular}

У 2017 роџі спостерігали певні пошкодження у рослин C. obovatus, C. coggygria 'Purpurea' та C. coggygria 'Royal Purple', які характеризувалися втратою тургору листків у денні години. Лише у C. coggygria ніяких пошкоджень не зафіксовано. Для визначення потенџійної посухостійкості ми дослідили динаміку вмісту загальної води та водний дефіџит у листках представників роду Cotinus (табл. 3).

Таблиџя 3. Вміст загальної води та водний дефіџит у листках представників роду Cotinus, \%

Table 3. Total water content and water deficit in leaves of the Cotinus genus representatives, \%

\begin{tabular}{|c|c|c|c|c|c|c|}
\hline \multirow[b]{3}{*}{ Таксон/Taхоп } & \multicolumn{6}{|c|}{ Дата/Date } \\
\hline & \multicolumn{2}{|c|}{15.06} & \multicolumn{2}{|c|}{16.07} & \multicolumn{2}{|c|}{14.08} \\
\hline & 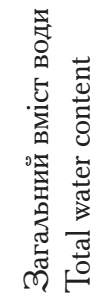 & 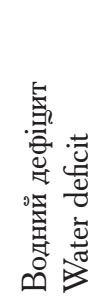 & 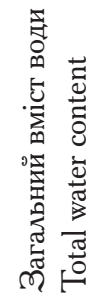 & 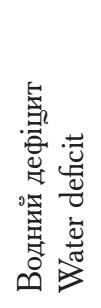 & 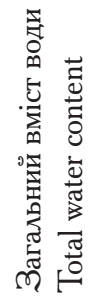 & 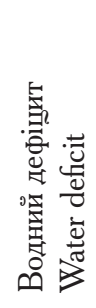 \\
\hline C. obovatus & 68,74 & 2,31 & 64,14 & 2,51 & 62,12 & 2,78 \\
\hline C. coggygria & 66,55 & 2,18 & 62,45 & 2,45 & 61,23 & 2,87 \\
\hline C. coggygria 'Royal Purple' & 63,80 & 1,78 & 61,12 & 1,82 & 60,23 & 1,83 \\
\hline C. coggygria 'Purpurea' & 64,17 & 2,05 & 61,85 & 2,10 & 60,22 & 2,10 \\
\hline
\end{tabular}

Як свідчать результати дослідження, вміст загальної води у листках упродовж вегетаџійного періоду є відносно стабільним, і їі вміст до кінџя літніх місяџів становив від 60,22 до 68,74\%.
Зниження кількості загальної води в кінџі серпня в листках Cotinus можна пояснити початком некротичних проџесів (табл. 3). Так, у червні він становив 63,80-68,74\%, у липні - 61,12-64,14\%, 
а у серпні - 60,22-62,12\%. У середньому за датами вміст води змінювався в межах 60,22-68,74\%, тобто вміст загальної води у листках рослин від червня до липня зменшився на $3,42 \%$, від липня до серпня - ше на $1,44 \%$, а у загальному за дослідний період - на 4,86\%.

У різні періоди доби та протягом вегетаџї рослини відчувають водний дефіџит, тоді коли швидкість транспіраџї перевищує швидкість поглинання води кореневою системою. Така ситуајія виникає не тільки під час посухи, але й в умовах грунтового засолення, а також при низьких температурах. Здатність рослини адекватно реагували на водний дефіџит і виживати в умовах його дії залежить від ефективності захисних механізмів рослини. На клітинному рівні водний дефіџит виражається в утраті тургору (Genkel',1982; Alekhina, 2005).

Залежно від варіювання метеорологічних даних (табл.1) в періоди дослідження ми спостерігали різниџю у показниках водного дефіџиту рослин представників роду Cotinus (табл. 3). Найбільшим для всіх досліджуваних рослин він виявився у серпні, коли середня температура повітря складала $+24,2^{\circ} \mathrm{C}$, відносна вологість $-65 \%$, а також спостерігалася відсутність опадів. Найменшим водний дефіџит був у червні місяџі, при середній температурі повітря $+23,3^{\circ} \mathrm{C}$, відносній вологості $-71 \%$ та кількості опадів - 8,5 мм. У липні даний показник складав $2,8 \%$, при середній температурі $+18,5^{\circ} \mathrm{C}$, відносній вологості - 79\% та кількості опадів - 1,8 мм. Отже, з підвищенням температури, зменшенням відносної вологості повітря та кількості опадів, водний дефіџит у рослин роду Cotinus різко зростає.
Водоутримуюча здатність (втрата води листками за певний проміжок часу) і ступінь відновлення тургору може бути порівняльною характеристикою посухостійкості рослин. При џьому враховується здатність листків утримувати воду, період, за який листки втратили певну її кількість, здатність відновлювати тургор в кінџі в'янення, а також точка зневоднення, при якій відбувається повне відновлення тургору листками (табл. 4., рис. 1). Г.Н. Єремеєв (1964) вважав, шо чим більше часу необхідно для втрати $30-35 \%$ вологи від початкової маси, тим більше у рослин міститься глибоко зв'язаної води, шо безпосередньо вказує на потенџійну здатність переносити глибоке в янення, а здатність відновлювати тургор листків після такого в янення - про можливість без істотних змін поновлювати фізіологічні процеси в тканинах листків (Eremeev, 1964). (рис. 2).

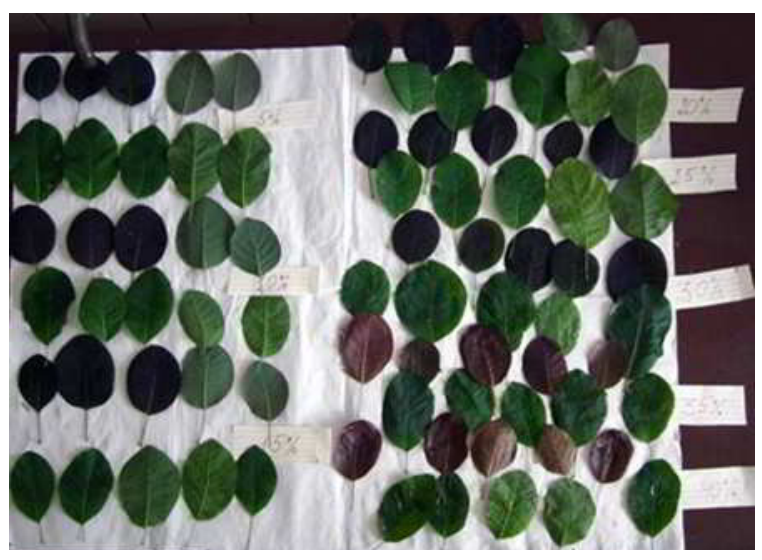

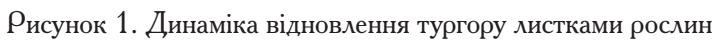
представників роду Cotinus

Figure 1. The dynamics of restoration of turgor by leaves of plants of the Cotinus genus

Таблиџя 4. Стійкість листків рослин представників роду Cotinus до зневоднення та їх тургоровідновлююча здатність

Table 4. Resistance of plants' leaves of the Cotinus genus representatives to dehydration and their turgorresistance ability

\begin{tabular}{|l|c|c|c|c|c|}
\hline \multirow{2}{*}{ Таксон/Taxon } & \multicolumn{5}{|c|}{ Плоша листків з відновленим тургором/Area of leaves with restored turgor, \% } \\
\cline { 2 - 6 } & \multicolumn{5}{|c|}{ Рівень зневоднення/ Dehydration level } \\
\cline { 2 - 6 } & $15 \%$ & $20 \%$ & $25 \%$ & $30 \%$ & $35 \%$ \\
\hline C. obovatus & 100,0 & $97,6 \pm 1,2$ & $89,1 \pm 1,8$ & $79,4 \pm 1,4$ & $63,2 \pm 5,2$ \\
\hline C. coggygria & 100,0 & $98,9 \pm 3,2$ & $92,0 \pm 4,5$ & $84,4 \pm 3,0$ & $75,4 \pm 4,1$ \\
\hline C. coggygria 'Royal Purple' & 100,0 & $96,8 \pm 2,2$ & $87,4 \pm 5,1$ & $79,4 \pm 5,1$ & $65,4 \pm 4,2$ \\
\hline C. coggggria 'Purpurea' & 100,0 & $97,4 \pm 1,1$ & $89,4 \pm 3,1$ & $80,1 \pm 2,7$ & $66,8 \pm 8,2$ \\
\hline
\end{tabular}


Повне відновлення тургору листків ми відмічали після втрати 15\% води. При втраті більше $15 \%$ води спостерігали незворотні пошкодження листкових пластинок. Найбільш стійкими до зневоднення виявилися листки C. coggygria. Після насичення водою листків C. coggygria, які втратили $35 \%$ води, відновило тургор 75,4\% площі листків (табл. 4), тоді як у C. obovatus џей показник становив 63,2\%. Ми вважаємо, шо втрата $35 \%$ води є критичною для життєдіяльності рослини, адже за такої втрати, відновлення тургору листків було менше 25-35\%.

За результатами дослідження водоутримуючої здатності листків представників роду Cotinus, з'ясувано, шо листки досягали 35 -відсоткового рівня втрати води протягом 20-24 годин. Найшвидше випаровували воду листки C. obovatus, які втратили 35\% води за 20 годин, повільніше C. coggygria 32,1\%, C. coggygria 'Royal Purple' - 25,8\%, C. coggygria 'Purpurea' - 26,0\% відповідно, шо свідчить про високу стійкість листків до зневоднення (рис. 2).

Висновки. Отже, за візуальними спостереженнями посухостійкості представників роду Cotinus встановлено, шо в умовах Наџіонального дендрологічного парку «Софіївка» НАН України рослини даного роду характеризуються високою фактичною посухостійкістю. Лабораторні дослідження показали, що вміст загальної води у листках упродовж

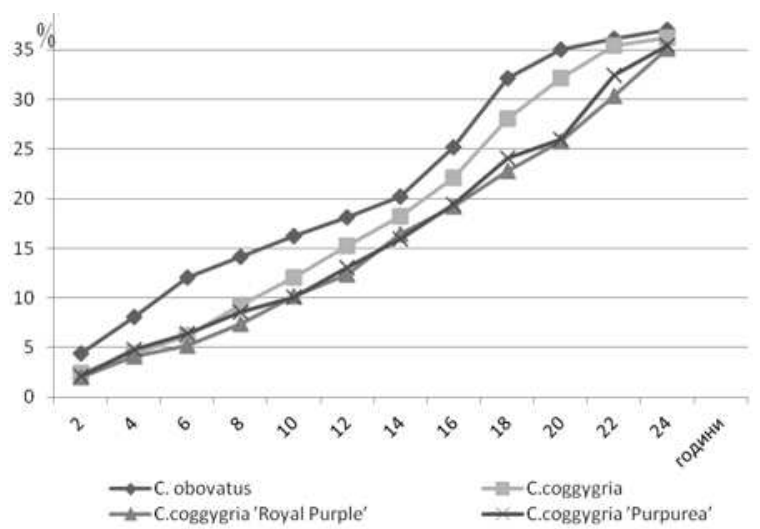

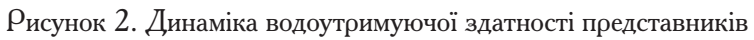
роду Cotinus

Figure 2. Water-repellent ability of representatives of the Cotinus genus

вегетаџійного періоду є відносно стабільним, і їі вміст до кінџя літніх місяџів складає від 60,22 до 68,74\%. У листках представників роду Cotinus, виявлено низький дефіџит води в період посухи та високу стійкість до зневоднення, що ознаками посухостійкості рослин. Аналіз отриманих даних дає можливість стверджувати, що представники роду Cotinus є посухостійкими рослинами придатними для широкого використання в зеленому будівниџтві.

\section{Список посилань/References}

Alekhina, N. D. (2005). Fiziologiia rastenij. Moskva: Akademiia. 640 p. (in Russian).

Borzakivs'ka, I. V. (1965). Zminy stanu vody v zv'iazku z zymostijkistiu siiansiv derevnikh roslyn. Aklimatizaciia j introdukciia novikh roslyn. S. 52-58. (in Ukrainian).

Dvorakovskij, M. S. (1983). Jekologiia rastenij. Moskva: Vysshaia shkola. 190 p. (in Russian).

Genkel', P. A. \& Oknina, E. Z. (1954). Diagnostika morozoustojchivosti rastenï po glubine pokoia ih tkanej i kletok (Metodicheskie ukazanija). Moskva: Izd-vo AN SSSR,. 37 p. (in Russian).

Genkel', P. A. (1982). Fiziologiia zharo- i zasukhoustojchivosti rastenii. Moskva: Nauka. 280 p. (in Russian).

Eremeev, G. N. (1964). Laboratorno-polevoj metod ocenki zasuhostojchivosti plodovyh i drugih rastenij i kratkie rezul'taty ego priminenija. Sb. nauchn. trudov Gos. Nikitsk. botan. sada. № 37. S. 472-489. (in Russian).

Klymenko, S. V. (1999) Biolohichni osoblyvosti ajvy dovgastoi v Lisostepu Ukrainy. Introdukciia roslyn. 2, S. 43-48. (in Ukrainian).

Kratkij agroklimaticheskij spravochnik Ukrainy (1976). [Ed.: Logvinova K. T.] Leningrad: Gidrometeoizdat. 256 p. (in Russian).

Kushnirenko, M. D. (1975). Fiziologïa vodoobmena i zasukhoustojchivosti plodovykh rastenij. Kishinev: Shtiinca. 216 s. (in Russian).

Kushnirenko, M. D. (1962). Vodnyj rezhim i zasukhoustojchivost' plodovyh rastenij. Kishinev: Shtiinca. 48 p. (in Russian).

Kushnirenko, M. D., Kurchatova, G. P. \& Krjukova, E. V. (1975). Metody ocenki zasukhoustojchivosti plodovyh rastenij. Kishinev: Shtiinca. S. 7-9. (in Russian).

Kushnirenko, M. D., Goncharova, E. A. \& Bondar', E. M. (1970). Metody izuchenija vodnogo obmena 
i zasukhoustojchivosti plodovyh rastenii. Kishinev: Shtiinica. 80 p. (in Russian).

Lishchuk, A. I. (1980). Opredelenie vodouderzhivajushchej sposobnosti i stojkosti k obezvozhivaniju list'ev i pobegov / Programma i metodika selekcii plodovyh, jagodnyh i orekhoplodnyh kul'tur. Michurinsk,. S. 473-476. (in Russian).

Oksantiuk, V. M. (2018). Rid Cotinus Mill. u Pravoberezhnomu Lisostepu Ukrainy (biologiia, ekologiia, introdukciia, vikoristannia): monografiia. Kyiv: PALYVODA A. V., 144 p. (in Ukrainian).

Pjatnickij, S. S. (1961). Praktikum po lesnoj selekcii. Moskva: Sel'hozizdat. 27. (in Russian).

УДК 58.036.2:58.036.5

\title{
Порівняльний аналіз зимо- та посухостійкості різновікових рослин виду Cladrastis kentukea (Dum.-Cours.) Rudd в умовах Національного дендрологічного парку «Софіївка» НАН України
}

\author{
Ольга Л. Порохнява \\ Національний дендрологічний парк «Софіївка» НАН України, м. Умань, Україна; e-mail: porokhniava@gmail.com \\ ORCID ID0000-0002-9636-9990
}

\section{Реферат.}

Meта. Роботу присвячено дослідженню зміни ступеня зимо- та посухостійкості у різновікових особин виду C. kentukea. Отримані результати дають змогу виявити, в якому онтогенетичному стані рослини найстійкіші до несприятливих умов навколишнього середовища. Методи. Періодизаџію онтогенезу C. kentukea виконано за класифікаџією вікових станів рослин Т. О. Работнова (1950) з доповненнями О.О. Уранова (1975) і його учнів. Посухостійкість визначено візуальним методом за 6-бальною шкалою С. С. П'ятниџького (1961). Візуальну оџінку зимостійкості виконано за 8-бальною шкалою С. Я. Соколова (1957), коефіџієнт зимостійкості визначено за методикою I. С. Косенка (2002). Результати. У період посухи спостерігали часткове пошкодження рослин C. kentukea у різних онтогенетичних станах, шо вплинуло на бал оџінки фактичної посухостійкості. Ювенільні рослини виявились найбільш чутливими до дії посухи, у деяких з них було зафіксовано локальні пошкодження країв листкових пластинок та втрату тургору. Рослини у генеративному стані в џілому не пошкоджувались дією посухи, лише інколи на окремих пагонах спостерігали опіки країв листкових пластинок у особливо посушливий період. Виявлено, шо чим більша різниџя між тривалістю росту пагонів і середньою тривалістю вегетаџії, тим вищий коефіџієнт зимостійкості. 3 віком у рослин виду C. kentukea ступінь зимостійкості підвишується. У ювенільних, іматурних та віргінільних рослин відмічене часткове підмерзання не здерев'янілих верхівок сильнорослих пагонів. Генеративні рослини в џілому не пошкоджуються низькими зимовими температурами. Висновки. 3 віком у рослин виду C. kentukea спостерігається підвишення середнього балу зимостійкості та посухостійкості. Високі показники зимо- та посухостійкості рослин у всіх досліджуваних вікових станах свідчать про високий рівень толерантності C. kentukea до несприятливих температурних умов навколишнього середовиџа.

Ключові слова: онтогенез, гідротермічний коефіџієнт, посуха, коефіџієнт зимостійкості. 